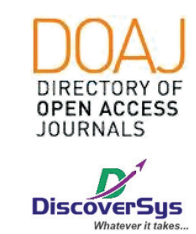

Published by DiscoverSys

\section{Inhibition effect of hydrocolloid irreversible alginate on soaking spray using aloe vera juice}

\author{
Dedi Sumantri,, Chaira Maulida
}

CrossMark

\title{
ABSTRACT
}

Introduction: Alginate impression material is the most commonly used in dentistry to get a negative mold of the oral tissues. Alginate impression material has imbibition effect when in contact with the liquid during the disinfection process. This study aimed to observe the imbibition effect on alginate impression material soaked and sprayed using Aloe vera juice.

Methods: The research method used was a laboratory experimental with pretest and posttest. Alginate was molded by using a mold with the size of $28 \mathrm{~mm}$ in diameter and $18 \mathrm{~mm}$ high. The results of molding alginate were soaked and sprayed using Aloe vera juice $100 \%$ for 5 minutes and 10 minutes. Calculation of imbibition was performed by weighing using digital scales. The normality tested by Shapiro-Wilk and the data were analyzed by Mann Whitney.

Result: The results showed that there were imbibition effects on alginate molding soaked and sprayed for 5 minutes and 10 minutes, the test indicated that there were significant differences $(p<0.05)$ between 10 minutes and 5 minutes soaking. Meanwhile, between 5 minutes and 10 minutes spraying, no significant difference was obtained ( $p>0.05)$.

Conclusion: This study concludes that it occurs the smallest imbibition effect on a spraying treatment using Aloe vera $100 \%$ for five minutes.
Faculty of Dentistry, Andalas University, Padang, Indonesia

${ }^{*}$ Corresponding: Dedi Sumantri, Faculty of Dentistry, Andalas University, Padang, Indonesia dedi.sumantri@dent.unand.ac.id

Diterima: 2018-05-22 Disetujui: 2018-07-28 Diterbitkan: 2018-12-1

Keywords: Inhibition, Aloe vera, alginate.

Cite This Article: Sumantri, D., Maulida, C. 2018. Inhibition effect of hydrocolloid irreversible alginate on soaking spray using aloe vera juice. Intisari Sains Medis 9(3): 24-29. D0I: 10.1556/ism.v9i3.274

\section{INTRODUCTION}

Impression materials in dentistry are used to obtain negative mold from the oral tissues. Impression results are used to create study model and work model to support the treatment plan. ${ }^{1}$ Impression materials based on their hardening methods are grouped into reversible and irreversible. The term irreversible denotes the occurrence of chemical reactions so that the material can not return to its original shapes, such as plaster of paris, zinc oxide eugenol mold paste, and hydrocolloid alginate that harden by chemical reaction, while the elastomeric impression material hardened with polymerization. Reversible means the impression material softened by heating and hardened by cooling without chemical changes, such as reversible hydrocolloid and compound. ${ }^{2}$

Alginate is a widely used as impression material in the dental clinic. This material is easy to use, does not require a lot of equipment, easy mixing, acceptable (tolerable) to patients and cheap enough. ${ }^{3}$ Alginate is a popular impression material and lots of dentists used it, but still many problems are found related to dimensional stability and poorly detailed prints so only used in initial impression only. ${ }^{4}$

Alginate impression contained $85 \%$ water can experience a shrinkage that evaporates water in the event of a temperature rise or when stored in the open air for a period of time, so the alginate impression will be contracted. ${ }^{5}$ Alginate impression has an imbibition property that absorbs water when contacted with water within a certain time so it will expand. In addition, alginate can also experience syneresis that is a continued sol reaction. ${ }^{6}$ Because of its vulnerability to expand it is necessary to watch out for changes in dimensions that may cause inaccuracies of alginate impression. ${ }^{7}$

Another factor to be considered is alginate is one of the transmission agents of infection in dental practice, so must be advised in order to avoid cross-infection transmission. Pathogenic microorganisms in saliva, debris, blood and pus may attach to the impression material during impression process and then spread through impression material itself. ${ }^{2}$

The American Dental Association (ADA) recommends that impression materials should be rinsed with water to remove saliva and blood attached to the impression material and then immersed in a disinfectant solution to avoid bacterial contamination before being sent to the laboratory. ${ }^{8}$ Alginate can be disinfected by using an immersion technique with a standard time of 10 minutes or by spraying techniques. ${ }^{2}$ The problem that often arises after the disinfection action is the dimensional change of accuracy of the impression material. Ideally, the immersion time is as short as possible, but it can disinfect the mold and avoid the possibility of scratching or damaging the detail of the mold surface. ${ }^{2}$ 
Types of materials that often used to disinfecting impression materials are divided into two, chemicals and natural materials. There are several types of chemical disinfection materials on the market, namely sodium hypochlorite, iodophor (biocide), phenol, glutaraldehyde (sporicidin), glyoxal glutaraldehyde (impresept), and chlorhexidine. ${ }^{9}$ Natural ingredients that can be used as a disinfectant and has been tested for its effectiveness against bacteria, among others extracts taken from garlic, betel leaf, tea tree oil, ginger, avocado leaf and aloe vera. $^{10}$

Aloe vera is one of the traditional medicinal plants containing antibacterial ingredients. ${ }^{11}$ Aloe vera is a natural insecticide that can grow around us. ${ }^{12}$ Based on the results of Trelie Boel's research on the anti-bacterial properties of some concentrations and the minimal growing inhibitory level of Aloe vera, Aloe vera contains a lot of chemicals found mainly in Aloe vera gel which consists of organic and inorganic components useful in medicine. ${ }^{13}$ Aloe vera extract contains antibacterial substances such as tannins, Aloctin A aminoglycoside, Anthraquinone Complex and Acemannan).

Research by White suggests that $100 \%$ Aloe vera can be used as a disinfectant and has an inhibitory effect on oral microorganisms on the surface of the impression starting from the first 3-5 minutes. ${ }^{14}$ A study conducted by Nugraha on antibacterial inhibition of aloe vera inhibition on growth of Streptococcus mutans bacteria showed that aloe vera with $100 \%$ concentration had inhibitory power with the best and effective category to inhibit the growth of Streptococcus mutans. ${ }^{15}$

Research conducted by Maryam aims to determine the effectiveness of Aloe vera extract in inhibiting the growth of Streptococcus sanguis bacteria. ${ }^{16}$ This research used Aloe vera extract with 5\%, 10\%, $25 \%, 50 \%$ and $100 \%$ concentration with negative control and positive control, then each concentration was diluted five times with sterile aquades liquid with replication of 3 times. The results obtained at concentrations of 5\% and 10\% already showed a clear but small diameter zone, this means that Aloe vera extracts of $5 \%$ and $10 \%$ have inhibitory but not significant enough to be used in inhibiting the growth of Streptococcus sanguis bacteria, while at concentrations of $25 \%, 50 \%$ and $100 \%$ also have seen a clear zone with a larger diameter, so it can be said that $100 \%$ Aloe vera concentration is the most effective concentration and followed by a concentration of $50 \%$ that can be used to inhibit growth of Streptococcus sanguis bacteria. The purpose of this study was to determine the effect of immersion and spraying imbibition by using Aloe vera juice on alginate16 prints.

\section{MATERIAL AND METHODS}

The sample of this study was the result of alginate mold that soaked and sprayed with Aloe vera juice with $100 \%$ concentration for 5 minutes and 10 minutes. The minimum required number of samples was six at each time with each technique, so the total sample size was 24 samples.

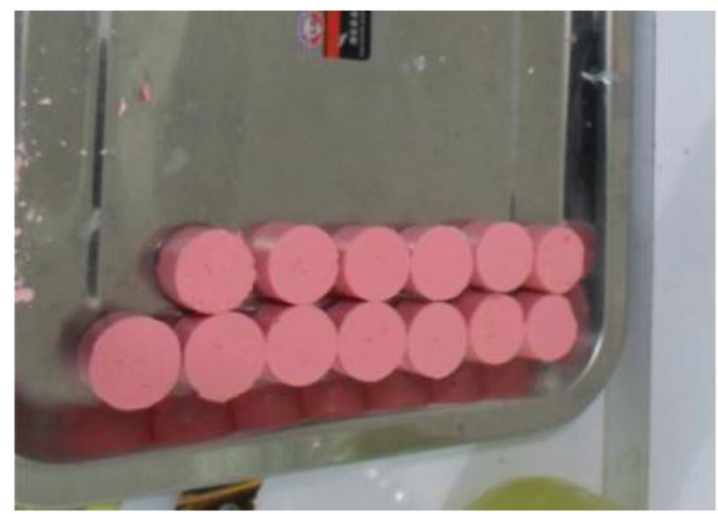

Figure 1 Sample of alginate mold

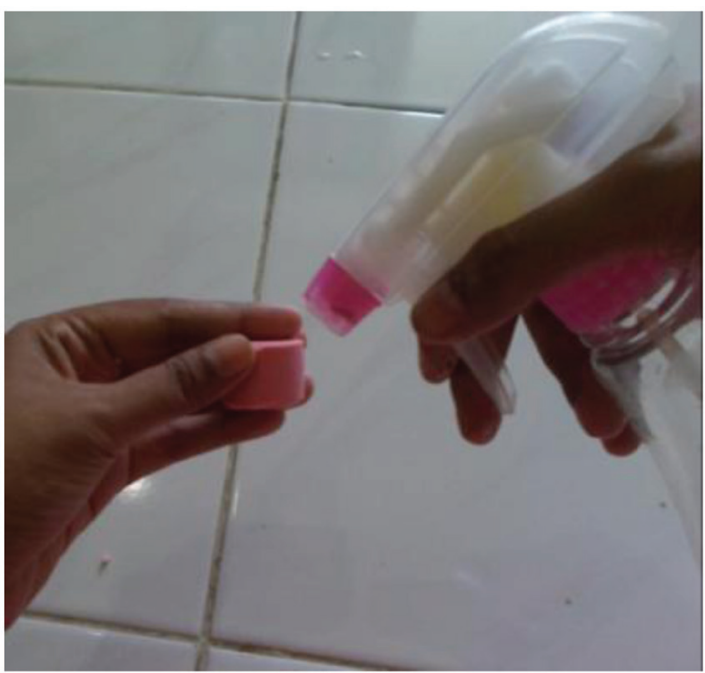

Figure 2 Sample sprayed by aloe vera

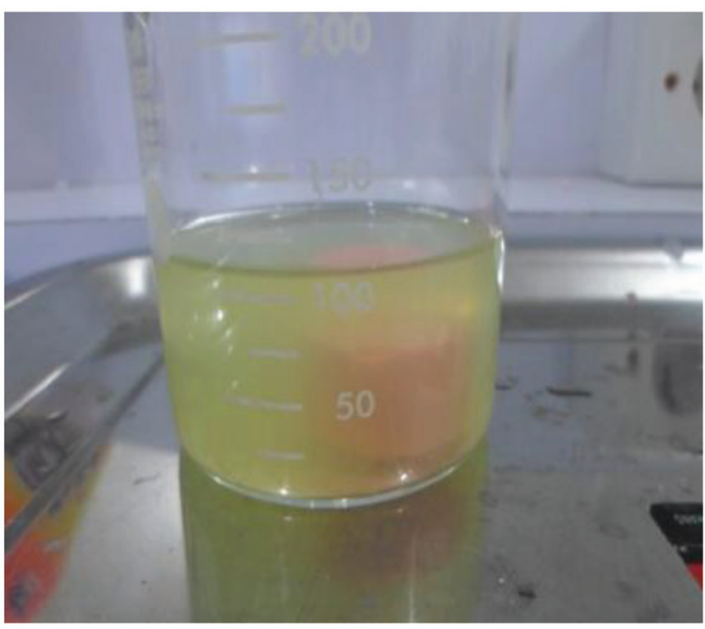

Figure 3 Alginate mold immersed in aloe vera juice 
Aloe vera juice was made from gel contained in Aloe vera leaves. Aloe vera used in this study were from the city of Padang, West Sumatra. Aloe vera were collected and made into juice on the same day. The gel or mucus from the aloe vera was separated from the skin of the leaves and then mashed by using a blender without mixing aquadest to obtain $100 \%$ concentration. Then Aloe vera juice was filtered using a shifter.

The alginate impression material with $\mathrm{W} / \mathrm{P}$ ratio according to the manufacturer's instructions were mixed on the rubber bowl until homogeneous. Then poured into the master die until it is full and covered with a glass with pressure for three minutes (until the mold is hardened). After the material hardened, the sample was removed from the master die and weighed as a data of 0 minutes. The soak-treated samples were immersed in 100\% Aloe vera juice for 5 minutes and 10 minutes. The spray-treated sample was sprayed with $100 \%$ Aloe vera concentration and then covered with a wet tissue sprayed with Aloe vera juice in advance with a duration of 5 minutes and 10 minutes. The data were analyzed by Mann Whitney and the normality tested by Shapiro-Wilk.

\section{RESULTS}

The results of the study were seen before and after samples soaked or sprayed in $100 \%$ Aloe vera disinfectant by measuring the sample weight before and after treatment.

This study used four groups of treatment to the sample. In the sample of treatment group 1 after removal from the mold weighed as data 0 minutes and then soaked in 100\% Aloe vera juice for 5 minutes. In the sample of treatment group

Table 1 Mean of weight changes, standard of deviation, minimum, and maximum after immersed in $100 \%$ aloe vera juice

\begin{tabular}{lccccc}
\hline Time of Immersion & $\mathbf{n}$ & Min (gram) & Max (gram) & Mean (gram) & SD \\
\hline 5 mins & 6 & 0.0 & 0.2 & 0.117 & 0.0753 \\
10 mins & 6 & 0.1 & 0.5 & 0.267 & 0.1366 \\
\hline
\end{tabular}

Table 2 Mean of weight changes, standard of deviation, minimum and maximum after sprayed by $100 \%$ aloe vera juice

\begin{tabular}{lccccc}
\hline Time of Immersion & $\mathbf{n}$ & Min (gram) & Max (gram) & Mean (gram) & SD \\
\hline 5 mins & 6 & 0.0 & 0.1 & 0.067 & 0.0516 \\
10 mins & 6 & 0.0 & 0.3 & 0.117 & 0.11169 \\
\hline
\end{tabular}

Table 3 Normality test (Saphiro-Wilk test)

\begin{tabular}{lccc}
\hline & Statistic & Df & p-value \\
\hline Imbibition effect & 0.861 & 24 & 0.004 \\
\hline
\end{tabular}

2 after removal from the mold weighed as data 0 minutes and then soaked in Aloe vera juice 100\% for 10 minutes. In the sample group 3 after removal from the mold weighed as data 0 minutes and then sprayed with $100 \%$ Aloe vera juice for 5 minutes. In the sample group 4 after removal from the mold weighed as data 0 minutes and then sprayed with 100\% Aloe vera juice for 10 minutes. All samples that have been soaked and sprayed were weighed again to see how big the imbibition is.

Each treatment group in each sample showed different weight gain. Alginate molds soaked and sprayed for 5 minutes and 10 minutes in Aloe vera juice showed different weight which means imbibition occurs in alginate impression material.

Results from the data in Table 1 showed that the smallest average weight change occurred in the treatment group soaking for 5 minutes of 0.117 grams with a minimum value of 0.0 grams and a maximum value of 0.2 grams.

The results of the data in Table 2 showed that the smallest average weight change occurred in the spray treatment group for 5 minutes was 0.117 grams, with a minimum value of 0.0 grams and a maximum value of 0.1 grams.

On the different test results Shapiro-Wilk showed that the results $\mathrm{p}=0.004$, means data not normally distributed. From the Mann-Whitney test results, it can be concluded that there was a significant difference $(p<0.05)$ between the dyestuffs of alginate printing material for 5 minutes in $100 \%$ Aloe vera concentration with 10 minutes of alginate printing in Aloe vera juice $100 \%$ concentration and immersion of alginate printing material for 10 minutes in Aloe vera 100\% concentration juice by spraying alginate printing material for 5 minutes using $100 \%$ Aloe vera juice concentration. In the other different test, there was no significant difference $(p>0.05)$ (Table 4$)$.

From the analysis result of the average table of the whole data (Table 5) it can be concluded that the spray treatment group for 5 minutes has the smallest average compared with the other treatment group ( $0.067 \mathrm{gr})$, while the treatment group for 10 minutes has the largest average of $0.267 \mathrm{gr}$.

\section{DISCUSSION}

A good dental impression is if the accuracy guaranteed and does not experience dimensional changes during casting. Dimensional changes in alginate are influenced by several factors; caused by pressure received by the gel on the impression tray during gelation process, imbibition process and syneresis. Dimensional stability is the ability of alginates to maintain accuracy over a certain time interval. $^{7}$ 
Table 4 Mann Whitney test

\begin{tabular}{lcc}
\hline Treatment Groups & Compared with & p-value \\
\hline Soaked 5 mins & Soaked 10 mins & $0.038^{\star}$ \\
Soaked 5 mins & Sprayed 5 mins & 0.206 \\
Soaked 5 mins & Sprayed 10 mins & 0.866 \\
Soaked 10 mins & Sprayed 5 mins & $0.008^{\star}$ \\
Soaked 10 mins & Sprayed 10 mins & 0.071 \\
Sprayed 5 mins & Sprayed 10 mins & 0.485 \\
\hline
\end{tabular}

Table 5 Mean of data

\begin{tabular}{lc}
\hline Treatment Groups & Mean (grams) \\
\hline Soaked 5 mins & 0.117 \\
Soaked 10 mins & 0.267 \\
Sprayed 5 mins & 0.067 \\
Sprayed 10 mins & 0.117 \\
\hline
\end{tabular}

Disinfecting action is killing disease-causing microorganisms thus reducing the possibility of infection by killing microorganisms micro pathogen. To prevent cross infection between the patient and the dentist the dental impression is soaked in disinfectant or sprayed with disinfectant. ${ }^{11}$

Alginate impression materials contained sodium or potassium alginate. In sodium or potassium alginate, the cations are attached to carboxyl ions to form salts. If the insoluble salt is formed by reaction of sodium alginate in solution with calcium salt, calcium ions will replace sodium ions in 2 adjacent molecules to form crosslinks between two molecules with the development of the reaction, crosslinking of the molecular complex or polymer network will be formed. ${ }^{12}$

$100 \%$ Aloe vera juice has antibacterial effect so it can be used as a disinfectant. The use of Aloe vera juice as disinfectant let the impression contacted with the liquid so it can affect the stability of the dimensions. ${ }^{13}$ Disinfectants may be applied to the alginate mold by either soaking or spraying.

Aloe vera extract contains antibacterial substances such as tannin, samponin, phenol, aminoglycoside Aloctin A, Anthraquinone and Acemannan Complex. A study by White suggests that $100 \%$ Aloe vera can be used as a disinfectant and has an inhibitory effect on oral microorganisms on the surface of the mold starting from the first 3-5 minutes. ${ }^{14}$ A study conducted by Nugraha on antibacterial inhibition of aloe vera inhibition on growth of Streptococcus mutans bacteria showed that aloe vera with $100 \%$ concentration had inhibitory power with the best and effective category to inhibit the growth of Streptococcus mutans. ${ }^{15}$
In table 1, the average weight increases of alginate after soaking for 5 and 10 minutes was showed. In each sample, there was a change of weight indicating the occurrence of an imbibition effect. The resultant alginate mold after treatment was given greater weight than before the treatment was administered. This is in accordance with that stated by Muzzafar et al. that alginate printing material changes occur after the printing material is soaked in disinfectant. Muzzafar et al. concluded that the absorption of the alginate molding material led to the expansion, which in alginates contained ions such as $\mathrm{Na}, \mathrm{SO} 42-$, PO43- as osmotic potentials. ${ }^{17}$ Saito et al. also revealed that the osmotic pressure between the alginate gel and the immersion solution caused alginate to expand when the solution was soaked with a disinfectant solution. ${ }^{18}$

In table 2, the average weight increase of alginate after spraying for 5 and 10 minutes were showed. Similarly, in this sample of spraying treatments, the sample showed a change in weight between before spraying and after being sprayed. This occurs because of the interaction between the fiber-shaped alginate structure with water that fills alginate capillaries. ${ }^{7}$

Table 4 shows the results of the Mann Whitney hypothesis test. In this table shows that there was a significant difference $(\mathrm{p}<0.05)$ between soaking for 10 minutes with soaking for 5 minutes. This is in accordance with the theory that the longer the immersion time will result in the alginate mold experiencing an increasingly large imbibition so that the water content in it is increased which causes the mold to be inaccurate. Plus the alginate impression material contains a lot of water that is about $85 \%$, so it tends to occur distortion caused by the expansion associated with the imbibition character of the alginate mold. ${ }^{18}$

The same thing also happened on different test between samples with soaking treatment for 10 minutes with spraying for 5 minutes. In Mann Whitney test results showed a significant difference $(p<0.05)$ between immersion for 10 minutes with spraying for 5 minutes. Descriptively, the value of weight change in the sample with the immersion treatment for 10 minutes is greater than the sample with spraying treatment for 5 minutes. This means that the spraying technique for 5 minutes is preferable compared to the immersion technique for 10 minutes.

In table 4 it also showed no significant difference ( $p>0.05$ ) between spraying for 5 minutes and spraying for 10 minutes. This occurs because in this spraying technique the storage time is relatively short and less absorbent fluid, so the imbibition is 
also less and the dimensional changes in the mold are also smaller. ${ }^{2}$ In spraying techniques, there is a balance between the imbibition process and the syneresis process. The imbibition process occurs when the disinfectant is sprayed on the alginate mold while the syneresis process occurs after the spraying process. Alginate molds that are not submerged after spraying are left open at room temperature caused the process of syneresis, so that the process of entry and discharge of water on alginate molds tend to be balanced. ${ }^{9}$ The results of this study are not much different from the research conducted by Valdina et al. in his research on the stability of dimensional alginate after spraying betel leaf infusion as a disinfectant for 5 minutes and 10 minutes showed that there was no significant difference between the two treatments. ${ }^{19}$ Table 4 also showed no significant difference $(p>0.05)$ in different test between samples with 5 minutes of soaking treatment with samples with spraying treatment 5 minutes, samples with 5 minutes immersion treatment with sample with spraying treatment 10 minutes, and a sample with a 5-minute spraying treatment with an immersion treatment for 10 minutes, so it can be concluded that although the technique and timing are different but statistically there is no clear difference in the weight changes of the mold.

Table 5 showed the average changes in the overall weight of the treatment data for the sample. This table showed that the sample by treatment using immersion technique has a greater imbibition effect compared to spraying technique. Samples with a 10-minute immersion treatment have the greatest imbibition compared to the others. This is because the submersion immersion technique is submerged all into the disinfectant liquid so that the disinfectant liquid is absorbed. The presence of webbing on the alginate pattern will retain the absorbed fluid causing imbibition and dimensional changes, as well as a longer duration of time, i.e. 10 minutes, lead to greater absorption. ${ }^{20,21}$

The fifth table also shows that samples treated by spraying technique for 5 minutes have the smallest of the imbibition effects compared to others, so it can be concluded that using spraying technique with duration of 5 minutes is recommended. This is due to the treatment of fluid spraying technique that is absorbed less, the duration of time used is relatively short, i.e. 5 minutes, and the imbibition is happening also less so that the dimension change the mold is also smaller.

The difference of weight in each sample is caused by various factors, among them is the compressed stress which is not balanced with strain when removing alginate from the mold or master die, mixing technique using manual technique, and the possibility of difference of mixing speed in each sample due to alginate dough mixing done once for one sample, and uncontrollable room temperature during the research.

\section{CONCLUSION}

Based on the effects of imbibition, spraying techniques using Aloe vera juice as a disinfectant material can be used as an alternative because it has a lower imbibition effect so that dimensional stability is better. Further research on the effectiveness of Aloe vera against alginate impression material using spraying technique with various concentrations in microbiology is needed.

\section{REFERENCES}

1. Combe EC. Sari Dental Material. Jakarta: Balai Pustaka; 1992. p. 211.

2. Anusavice KJ. Buku ajar ilmu bahan kedokteran gigi. Alih Bahasa Budiman JA, Purwoko S. Jakarta: EGC; 2003. P. 94-114.

3. Fitrian D. Pengaruh Desinfeksi dengan Berbagai Macam Larutan Desinfektan pada Hasil Cetakan Alginate terhadap Stabilitas Dimensional. Universitas Jember. 2013.

4. Sudjarwo I. Pengaruh Perendaman Cetakan Alginate dalam Larutan Desinfektan Sodium Hipoklorit Dan Perasan Aloe Vera terhadap Stabilitas Dimensional. Universitas Hasanudin. 2014.

5. Mitchell DA, Mitchell L. Oxford Handbook Of Clinical Dentistry (e-book). New York: Oxford; 2005.

6. Joseph WO. Dental Materials and Their Selection $3^{\text {rd }}$ ed. Chicago: Quintessence Publishing C; 2002.

7. Imbery TA, Nehring J, Janus, C, Moon PC. Accuracy and Dimensional Stability Of Extended-Pour and Conventional Alginate Impression Materials. J Am Dent Assoc. 2010;141(1):32-9.

8. Bhat VS, Shetty MS, Shenoy KK. Infection control in the prosthodontic laboratory. The Journal of Indian Prosthodontic Society. 2007;7(2):62.

9. Noort RV. Dental Materials. Third Edition. United State: ELSEVIER; 2007. p. 186-207.

10. Larasati I, Herdiva OD. Efektivitas Ekstrak Daun Alpukat sebagai Desinfektan Bahan Cetak Alginat dengan Metode Perendaman. Purwokerto: Fakultas kedokteran gigi Universitas Jendral Soedirman; 2012.

11. Sari DP, Herawati D, Hendrawati. Irigasi Larutan Ekstrak Lidah Buaya(Aloe Vera) 5\% terhadap Akumulasi Plak Penderita Gingivitis. Majalah kedokteran gigi. 2009;16(2):99-101.

12. Arivia S, Kurniawan B, Zuraida R. Efek Larvasida Ekstrak Daun Lidah Buaya (Aloe Vera) Terhadap Larva Aedes Aegypti Instar III. Medical Journal of Lampung University. 2013;2(5):137-46.

13. Boel T. Daya Antibakteri pada Beberapa Konsentrasi dan Kadar Hambat Tumbuh Minimal dari Aloe Vera. Dentika Dental Jurnal. 2002;7(1):58-66.

14. White, robert. 2015. Patents; "Disinfectant Compositions and Uses There of" in Patent Application Approval Process. Life Science Weekly. Available from http://eresources.perpusnas.go.id:2057/docview/1658110689/fulltext/24DEF4C5B4F4F12PQ/1?accountid=25704. Accessed December 22,2015 .

15. Nugraha A. Uji Daya Hambat Antibakteri Ekstrak Lidah Buaya Terhadap Pertumbuhan Bakteri Streptococcus Mutans. Universitas Andalas. 2014.

16. Maryam I. Efektifitas Ekstrak Aloe Vera Terhadap Pertumbuhan Bakteri Streptococcus Sanguis. Universitas Hasanudin. 2013. 
17. Muzaffar D, Ahsan SH, Afaq A. Dimensional changes in alginate impression during immersion in a disinfectant solution. JPMA-Journal of the Pakistan Medical Association. 2011;61(8):756

18. Saito S, Ichimaru T, Araki Y. Factors affecting dimensional instability of alginate impression during immersion in the fixing and disinfectant solutions. J Dental Materials. 1998;4:294-300.

19. Valdina NF, Priyawan R, Arya IW. Stabilitas dimensi Hasil Cetakan Alginat Setelah Dilakukan Penyemprotan Infusan Daun Sirih Merah (piper crocatum ruiz dan pav) 50\% Sebagai Desinfektan. Dentino Jurnal Kedokteran Gigi. 2014;2(1):74-78.

20. Craig RG, Power JM. Restorative Dental Materials, 11th Editon. St. Loius: CV Mosb; 2002. p. 281.
21. Sukrama, D.M., D.M. Wihandani and A.P. Manuaba. 2017. Topical binahong (Anredera cordifolia) leaf extract increases interleukin-6 and vegf (vascular endothelial growth factor) during burn wound healing in wistar rats infected with pseudomonas aeruginosa. Biol. Med. $9(1): 1-6$

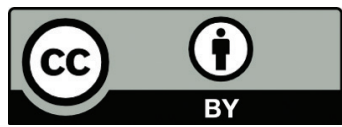

This work is licensed under a Creative Commons Attribution 